\title{
Isolation, identification, preservation and deter- minations of lactic acid bacteria from chicken's gut content at 26 days old
}

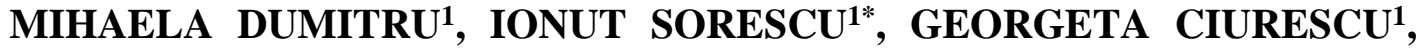 \\ MIHAELA HABEANU ${ }^{1}$
}

${ }^{1}$ National Research Development Institute for Animal Biology and Nutrition (IBNA), Balotesti, Ilfov, Romania

\begin{abstract}
Chichens's gastrointestinal (GI) tract presents a large bacterial diversity and can be a beneficial source in order to the isolation of probiotics candidates. In this study, twentythree strains from Lactobacillus genus (one strain of L. acidophilus biotype 1, eight strains of $L$. acidophilus biotype 3, one of $L$. crispatus, five of $L$. fermentum biotype 1 , two of $L$. brevis biotype 2, five of $L$. salivarius and one strain of $L$. delbrueckii subsp. delbrueckii) were isolated, cultured, and conserved from ileum and cecum digesta of sixteen chickens, 26 days old, based on their phenotypic characters. The strains confirmation was done by apiwebTM API 50 CHL V.5.1, BioMerieux (France) software, and ABIS online soft. The Lactobacillus strains $\left(10^{6}-10^{8} \mathrm{CFU} / \mathrm{g}\right.$ intestinal content) level in the selective medium were determined. The growth of Lactobacillus strains conserved at $4^{\circ} \mathrm{C}$ (from 48 days to 7 months) and room temperature (from 48 to 90 days) was evaluated. This study showed that chickens can be a stable source for isolating possibly active probiotic lactic acid bacteria (LAB). From Lactobacillus strains isolated and identified, respectively L. fermentum biotype 1 and L. brevis biotype 2 are theoretically suitable for continual testing of probiotic properties.
\end{abstract}

Keywords Lactobacillus spp., gut, chicken, phenotypic identification, preservation.

To cite this article: DUMITRU M, SORESCU I, CIURESCU G, HABEANU M. Isolation, identification, preservation and determinations of lactic acid bacteria from chicken's gut content at 26 days old. Rom Biotechnol Lett. 2021; 26(4): 2765-2772. DOI: $10.25083 / \mathrm{rbl} / 26.4 / 2765-2772$ 


\section{Introduction}

Gastrointestinal (GI) health is a prime focus of interest in poultry nutrition and production. The gastrointestinal microbiota and their metabolic products play an important role in digestion, absorption, and metabolism of nutrients, and improve the overall health and growth performance of poultry (YADAV \& JHA [1], SLIZEWSKA \& al [2], RODRIGUES \& al [3]). The composition of the GI microflora in animals is very relevant and may protect hosts from pathogens (BARBOSA \& al [4], CIURESCU \& al [5], DUMITRU \& al [6]).

Lactobacillus species are one of the predominant bacterial genera in the GI tract of poultry, non-pathogenic with a record of harmless use as probiotic bacteria (AMITROMACH \& al [7], DUAR \& al [8], WAITE \& TAILOR [9], WEI \& al [10], LU \& al [11]). LABs are proposed to reestablish the ecological balance of the gut and mucosal membranes integrity (AAZAMI \& al [12]). During the first 2 to $4 \mathrm{~d}$ post-hatch, streptococci and enterobacteria colonize the small intestine and cecum of chicks. After the first week, Lactobacillus becomes a significant component of the small intestine (AAZAMI \& al [12], ZHU \& al [13], SWIDA \& BINEK [14], NOOHI \& al [15]). AZIZ \& al [16] affirmed that approximately $70 \%$ of the microbial flora from different sections of the chickens' GI vary; for example, ileum chickens are composed of autochthonous Lactobacillus spp., while the caecum segment becomes more conquered by lactobacilli as the animal ages.

Probiotics, or direct-fed microbials, have been defined as "live microorganisms that, when administered in adequate amounts, confer a health benefit on the host" (PINEIRO \& STANTON [17]). Administration of the probiotic based on Lactobacillus spp. in poultry feed progresses not only the feed digestion process, as well as nutrient absorption. Moreover, probiotics administration improves the growth of animal performance, increases the immune responses, and counterbalancing several enterotoxins (AL-KHALAIFA \& al [18]). Furthermore, probiotics supplementation diminish the risk of GI colonization with foodborne pathogens, such as Campylobacter (GHAREEB \& al [19], NEAL-McKINNEY \& al [20], KHAN \& al [21]), Clostridium (LI \& al [22], DUMITRU \& al [23]) and Salmonella (KIZERWETTER-SWIDA \& BINEK, [24], TELLEZ \& al [25], KOWALSKA \& al [26]), and intensify the poultry diets security (GAGGİA \& al [27]).

Many strains of Lactobacillus have been selected as probiotics based on their in vitro inhibitory effects on chicken pathogenic bacteria (KOWALSKA \& al [26], FENG \& al [28], REUBEN \& al [29]). Moreover, ZOU \& al [30] demonstrated, by meta-analysis, that Lactobacillus elicit a differentiating effect on the chicken cecum microbiom, the majority of taxa displaying significant numbers of negative (Lachnospiraceae, Ruminococcaceae) or positive (Lactobacilli, Bacteroides, Clostridiales and Christensenellaceae) relationships with Lactobacillus, suggesting a major influential role for this genus.

This study aimed to isolate, characterize, and assess Lactobacillus spp. from the GI content of 26 days old broiler chickens with special attention to their properties as a possible probiotic candidate in poultry feed.

\section{Materials and Methods}

The experimental trial was agreed by the Ethical Committee of the National Research Development Institute for Biology and Animal Nutrition (IBNA Balotesti), in agreement with Romanian legislation (Law 305/2006, Directive 2010/63/EU) for supervision and safety of animals used for experimental purposes.

\section{Isolation and phenotypic characterization of Lactic acid bacteria}

The intestinal content from sixteen randomly selected healthy chickens (26 days old) was collected aseptically in sterile plastic tubes and processed for Lab's isolation. One gram of ileum and cecum digesta of each chicken was aseptically transferred and homogenized into $15 \mathrm{~mL}$ sterilized tube with $7 \mathrm{~mL}$ BHI broth (Brain Heart Infusion, Oxoid, Ltd., Hampshire, England) and $2 \mathrm{~mL}$ glycerol, followed by frozen at $-20^{\circ} \mathrm{C}$ until testing. After defrost the method of MOUNTZOURIS \& al [31] and completed by SORESCU \& al [32] with Gram staining of smears from colonies morphology confirmation of Lactobacillus by microscopic examination was followed. The catalase test was done and CFU/g gut content was determined.

\section{Identification of bacterial strains}

Isolated bacteria were phenotypic identified based on Bergey's Systematic Manual Bacteriology, ABIS online, and APIweb ${ }^{\text {TM }}$ API 50CHL soft BioMerieux (France), as described by several authors (SORESCU \& al [32]; STOICA \& SORESCU [33]; PELINESCU et al [34]).

\section{Lactic acid bacteria preservation}

Bacterial strains viability was tested after 48-90 days, 4 and 7 months. The preservation for an extensive period (2 years) was done at $-80^{\circ} \mathrm{C}$, with supplementation of $20 \%$ glycerol.

\section{Results and Discussion}

The isolated were pre-identified by Gram staining, catalase reaction, and taxonomically classified as fallow: morphological (Gram-positive bacteria with non-sporeforming rods), cultural (anaerobic conditions), and biochemical aspects (negative catalase result).

Based on biochemical properties, Lactobacillus spp. were identified with the application of API 50CHL test. Accordingly, twenty-three strains of the Lactobacillus genus belonging to 6 species ( $L$. acidophilus biotype 1 IBNA 21, L. acidophilus biotype 3 IBNA 23, 26-28, 30, $35,36,40$, L. crispatus IBNA 22, L. brevis biotype 2 IBNA 24, 31, L. fermentum biotype 1 IBNA 25, 32, 37, 42, 43, L. delbrueckii subsp. delbrueckii IBNA 38 and L. salivarius IBNA 29, 33, 34, 39, 41) were isolated on MRS medium, identified and preserved from sixteen chickens (26 days old) intestinal content (ileum and cecum).

Figures 1-3 illustrate smears (Gram staining, x 1000) from $L$. acidophilus biotype 3 IBNA 35, L. fermentum biotype 1 IBNA 37 and L. salivarius IBNA 33 cultures in MRS broth medium.

The taxonomic criteria for identified and selecting Lactobacillus strains to be used as probiotics in poultry feed is summarized in Table 1. 
Table 1. Phenotypical characters of Lactobacillus strains isolated from chicken's tract (26 days old)

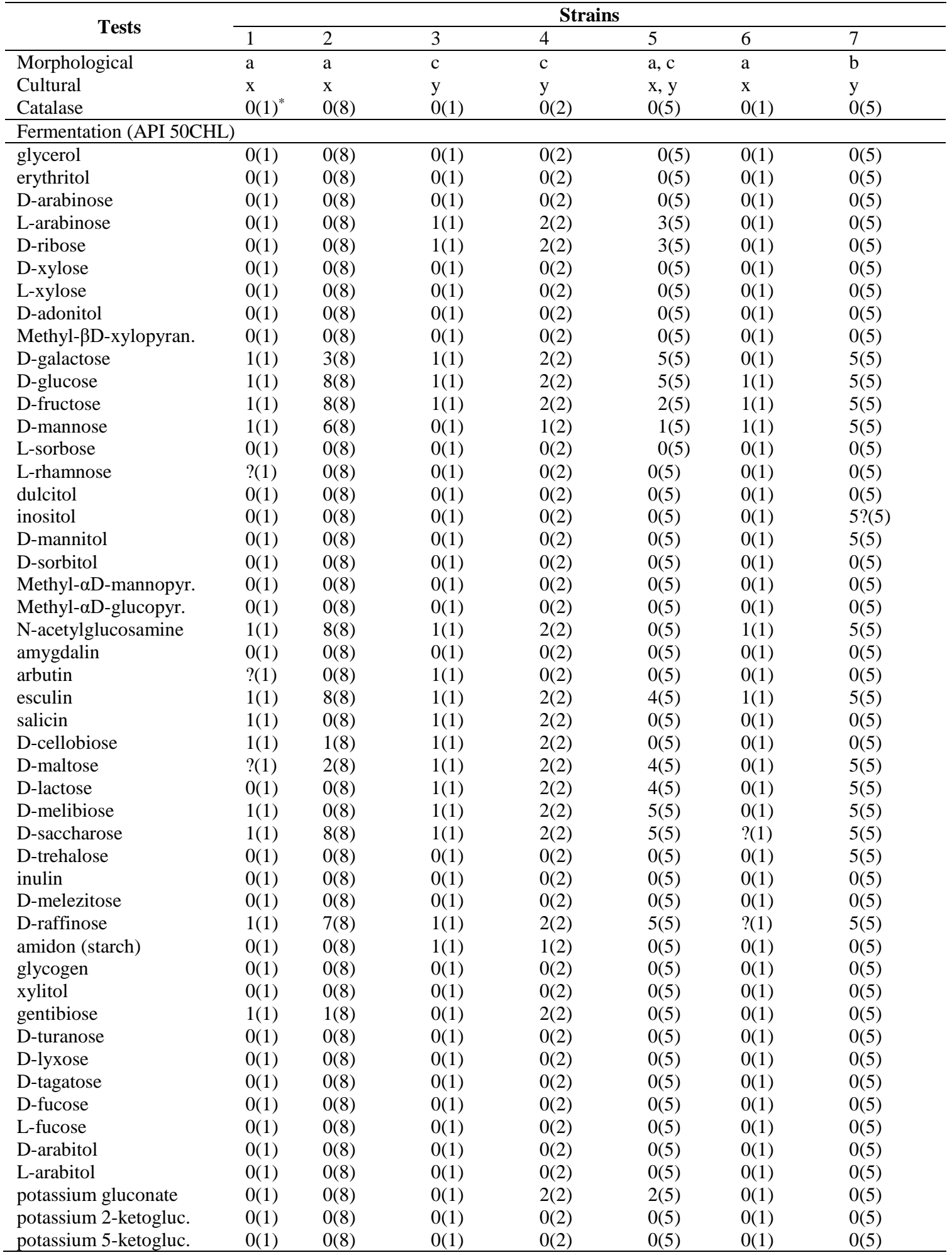

1=L. acidophilus biotype 1 IBNA 21; 2= L. acidophilus biotype 3 IBNA 23, 26-28, 30, 35, 36, 40; 3= L. crispatus IBNA 22; 4=L. brevis biotype 2 IBNA 24, 31; 5= L. fermentum biotype 1 IBNA 25, 32, 37, 42, 43; 6= L. delbrueckii subsp.delbrueckii IBNA 38 $7=$ L. salivarius IBNA 29, 33, 34, 39, 41;

$\mathrm{a}=$ Gram positive, non-spore forming rods, congregated in pairs or chains, filaments and, rarely, in palisade;

$\mathrm{b}=$ Gram positive short rods, with rounded end, non-spore forming, arranged in pairs, short chains or small, irregular clumps;

$\mathrm{c}=$ Gram positive short and thick rods or coccoid cells, non-spore forming, arranged in short chains and irregular clumps;

$\mathrm{x}=$ small colonies, $0.5-1.5 \mathrm{~mm}$ in diameter, rarely larger, up to $2.0 \mathrm{~mm}$, smooth type, round, opaque, transparent or semi-transparent, whitish, grey or colourless on MRS agar plate;

$\mathrm{y}=$ large colonies, $2.0-4.0 \mathrm{~mm}$ in diameter, rarely smaller, smooth type, round, white, opaque;

$*=$ number of positive strains from number of tested strains;

$?=$ weekly, positive, dubious. 


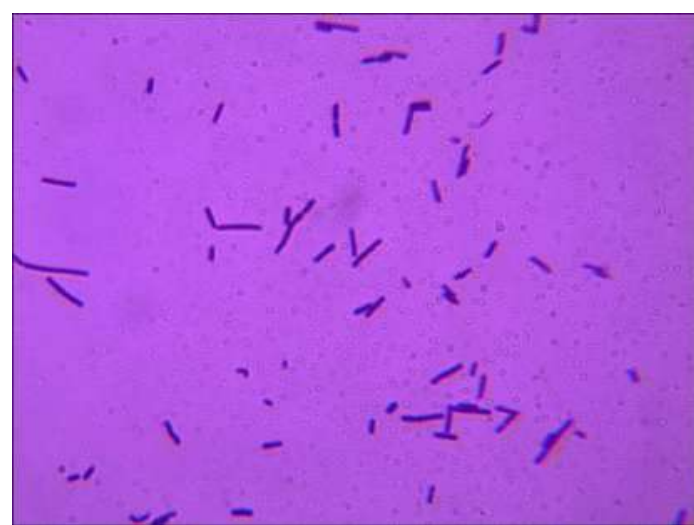

Figure 1. L. acidophilus biotype 3 IBNA 35

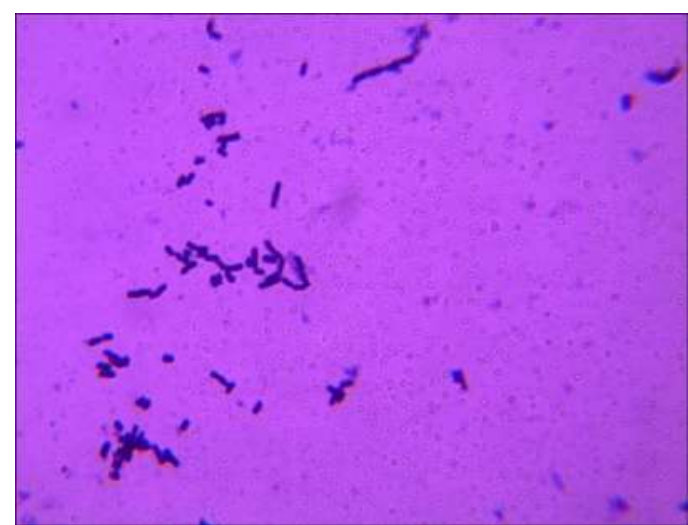

Figure 2. L. fermentum biotype 1 IBNA 37

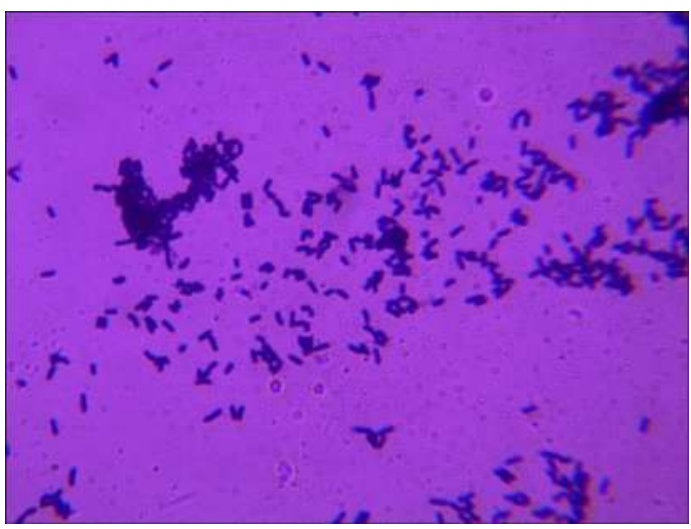

Figure 3. L. salivarius IBNA 33

A total of $23 \mathrm{LAB}$ strains were isolated from the gut content of healthy broiler chickens (26 days old).

Morphological characters of bacilli, a grouping of them, cultural aspects (colony size, colour and degree of opacity/transparency) and specifically, biochemical properties (fermentation of L-arabinose, D-ribose, D-galactose, D-fructose, D-mannose, D-glucose, inositol, D-mannitol, N-acetylglucosamine, salicin, arbutin, esculin, D-cellobiose, D-maltose, D-melibiose, D-lactose, $\mathrm{D}$-saccharose, D-raffinose, starch, gentibiose, and potas- sium gluconate) involve importantly differences between isolates cultures. Carbohydrate tests produced a blue color for a positive result or red-orange color for a negative result agreeing to manufacturer instructions. It can be remarked that Lactobacillus isolates from chickens ferment more carbohydrates (21) than those from turkeys (15) (SORESCU \& al [32]), which may interfere with the absorption and digestion of these sugars in the host gut segment if they are used in diets of poultry.

In Table 2 are presented the origin and the quantitative level of the isolate's occurrence in chicken's digesta.

Table 2. Lactobacillus spp. strains existence in chickens' intestinal content (26 days old)

\begin{tabular}{|c|c|c|}
\hline Strains types & Source, sample number & CFU/g (log10) \\
\hline $\begin{array}{l}\text { L. acidophilus biotype } 1 \text { IBNA } 21 \\
\text { L. acidophilus biotype } 3 \text { IBNA } 23 \text {, } \\
\text { 26-28, } 30,35,36,40\end{array}$ & $\begin{array}{l}\text { cecum content, } 28 \text {. } \\
\text { ileum content, 29, 31; cecum } \\
\text { content, 32; ileum content, 35; } \\
\text { cecum content, 37; ileum content, } \\
\text { 43; cecum content, 44, } 46 .\end{array}$ & $\begin{array}{l}7.845+\mathrm{E} \\
7.301+\mathrm{E} ; 8.176+\mathrm{E} ; 7 ; 6.698+\mathrm{E} \\
8.477+\mathrm{E} ; 7.079+\mathrm{E} ; 8.845+\mathrm{E} \\
8.903+\mathrm{E}\end{array}$ \\
\hline L. crispatus IBNA 22 & ileum content, 29. & 6 \\
\hline $\begin{array}{l}\text { L. brevis biotype } 2 \text { IBNA } 24,31 \\
\text { L. fermentum biotype } 1 \text { IBNA } 25,32 \text {, } \\
37,42,43 \\
\text { L. delbrueckii subsp. delbrueckii IBNA }\end{array}$ & $\begin{array}{l}\text { cecum content, } 30,38 . \\
\text { ileum content, } 31 ; \text { cecum } \\
\text { content, } 41,44,49,49 .\end{array}$ & $\begin{array}{l}8.845+\mathrm{E} ; 7.778+\mathrm{E} \\
7.698+\mathrm{E} ; 8.447+\mathrm{E} ; 8.301+\mathrm{E} \\
7.875+\mathrm{E} ; 8.544+\mathrm{E}\end{array}$ \\
\hline L. salivarius IBNA 29, 33, 34, 39, 41 & $\begin{array}{l}\text { cecum content, } 45 \text {. } \\
\text { cecum content, } 35,41,42,45 \text {; } \\
\text { ileum content } 48 .\end{array}$ & $\begin{array}{l}7.698+\mathrm{E} \\
8.477+\mathrm{E} ; 8.361+\mathrm{E} ; 8 ; 8.113+\mathrm{E} \\
6.954+\mathrm{E}\end{array}$ \\
\hline
\end{tabular}


Unlike turkeys where, at the corresponding serial dilutions in PBS buffer, Lactobacillus spp. developed as pure culture bacteria, with one exclusion (when co-exist L. fermentum IBNA 18 and L. salivarius IBNA 19, so two strains from nine isolated are mixed), in chickens ten isolates from twenty-three co-exist with strains from other or same species of Lactobacillus sp. L. acidophilus biotype 3 co-exist with L. fermentum biotype 1 or L. crispatus, L. salivarius with $L$. fermentum biotype 1 and, interesting, co-exist 2 strains of L. fermentum biotype 1, IBNA 42 and 43 , which differ through some morphologically, culturally and biochemically characters. This polymorphism and variability are highlighted in Table 1.

In the cecum content, the CFU number of Lactobacillus/g is higher (7-8 $\left.\log _{10}\right)$ than in the ileum $\left(6-7 \log _{10}\right)$.

Table 3 presents the results of LAB strains identification by APIweb ${ }^{\mathrm{TM}}$ soft, API50 CHL V.5.1, BioMerieux (France), and ABIS online soft.

Table 3. Parallel LABs identification by APIweb ${ }^{\mathrm{TM}}$ soft, API50CHL V.5.1, BioMerieux (France) and ABIS online

\begin{tabular}{|c|c|c|}
\hline Strains & API, \% ID & ABIS, \% SIM \\
\hline L. acidophilus biotype 1, IBNA 21 & L. acidophilus 1, 91.7 & L. acidophilus, 92 \\
\hline L. acidophilus biotype 3 , IBNA 23 & L. acidophillus $3,97.7$ & $\begin{array}{l}\text { L. kunkeii, } 91 \\
\text { L. curvatus, } 89 \\
\text { L. acidophilus, } 81\end{array}$ \\
\hline IBNA 26 & L. acidophillus 3, 95.6 & $\begin{array}{l}\text { L. delbrueckii, } 92 \\
\text { L. acidophilus, } 78\end{array}$ \\
\hline IBNA 27 & L. acidophillus 3, 99.9 & $\begin{array}{l}\text { L. curvatus, } 86 \\
\text { L. acidophilus, } 78\end{array}$ \\
\hline IBNA 28 & L. acidophillus 3, 95.6 & $\begin{array}{l}\text { L. delbrueckii, } 92 \\
\text { L. acidophilus, } 78\end{array}$ \\
\hline IBNA 30 & L. acidophillus 3, 95.6 & $\begin{array}{l}\text { L. delbrueckii, } 92 \\
\text { L. acidophilus, } 78\end{array}$ \\
\hline IBNA 35 & L. acidophillus 3, 97.7 & $\begin{array}{l}\text { L. kunkeii, } 91 \\
\text { L. curvatus, } 89\end{array}$ \\
\hline IBNA 36 & L. acidophillus 3, 98.6 & $\begin{array}{l}\text { L. acidophilus, } 81 \\
\text { L. kunkeii, } 91\end{array}$ \\
\hline IBNA 40 & L. acidophillus 3, 98.1 & $\begin{array}{l}\text { L. curvatus, } 89 \\
\text { L. acidophilus, } 81 \\
\text { L. delbrueckii, } 89 \\
\text { L. acidophilus, } 79\end{array}$ \\
\hline L. crispatus, IBNA 22 & L. crispatus 90.2 & L. acidophilus 92 \\
\hline $\begin{array}{l}\text { L. brevis biotype 2: } \\
\text { IBNA } 24 \\
\text { IBNA } 31\end{array}$ & $\begin{array}{l}\text { L. brevis } 2,94.6 \\
\text { L. brevis } 2,94.3\end{array}$ & $\begin{array}{l}\text { L. } \text { oris, } 93 \\
\text { L. brevis (possibility of } \\
\text { L. buchneri), } 90 \\
\text { L. brevis (possibility of } \\
\text { L. buchneri), } 94\end{array}$ \\
\hline L. fermentum biotype 1: & L. fermentum 1, 96.9 & $\begin{array}{l}\text { L. similis, } 95 \\
\text { L. fermentum (possibility of } \\
\text { L. reuteri), } 92 \\
\text { L. kefiranofaciens, } 94\end{array}$ \\
\hline IBNA 25 & L. fermentum $1,88.3$ & $\begin{array}{l}\text { L. keftranofaciens, } 94 \\
\text { L. acidophilus, } 92 \\
\text { L. fermentum (possibility of }\end{array}$ \\
\hline IBNA 32 & L. acidophilus $3,10.9$ & $\begin{array}{l}\text { L. reuteri), } 85 \\
\text { L. fermentum (possibility of }\end{array}$ \\
\hline IBNA 37 & L. fermentum 1, 99.1 & $\begin{array}{l}\text { L. reuteri), } 92 \\
\text { L. kefiranofaciens, } 95 \\
\text { Lermentum (possibility of }\end{array}$ \\
\hline IBNA 42 & L. fermentum 1, 91.3 & $\begin{array}{l}\text { L. reuteri), } 85 \\
\text { L. antri, } 91\end{array}$ \\
\hline IBNA 43 & L. fermentum 1,97 & $\begin{array}{l}\text { L. similis, } 91 \\
\text { L. mucosae, } 90 \\
\text { L. fermentum (possibility of } \\
\text { L. reuteri), } 88\end{array}$ \\
\hline L. delbrueckii subsp. delbrueckii, IBNA 38 & $\begin{array}{l}\text { L. delbrueckii ssp. } \\
\text { delbrueckii, } 60.2\end{array}$ & L. delbrueckii ssp. delbrueckii, 91 \\
\hline $\begin{array}{l}\text { L. salivarius: } \\
\text { IBNA } 29 \\
\text { IBNA } 33 \\
\text { IBNA } 34 \\
\text { IBNA } 39 \\
\text { IBNA } 41\end{array}$ & $\begin{array}{l}\text { L. salivarius, } 98.9 \\
\text { L. salivarius, } 98.9 \\
\text { L. salivarius, low } \\
\text { discrimination } \\
\text { L. salivarius, low } \\
\text { discrimination } \\
\text { L. salivarius, } 98.9\end{array}$ & $\begin{array}{l}\text { L. salivarius, } 94 \\
\text { L. salivarius, } 90 \\
\text { L. salivarius, } 94 \\
\text { L. salivarius, } 97 \\
\text { L. salivarius, } 91\end{array}$ \\
\hline
\end{tabular}

Identification by APIweb is show the \% ID (\% identification), respectively \% SIM for ABIS (\% similarity). 
L. acidophilus biotype 1, L. delbrueckii ssp. delbrueckii, L. salivarius and $L$. brevis biotype 2 were obtained a similar systematic classification, sometimes even with identical percentage results. Instead, for L. acidophilus biotype 3 , which is biochemically close to L. fermentum, and for L. fermentum biotype 1, ABIS soft is not yet advanced enough for precise identification.
CATO \& al [35]) reported that L. crispatus is similar to L. acidophilus group A2 because the strains of L. crispatus and L. acidophilus group A2 involve 100\% DNA homology. So, the L. crispatus IBNA 22 strain was identified as L. acidophilus by the ABIS software, L. crispatus species being not registered in the ABIS database. Lactobacillus types viability which are conserved at $4^{\circ} \mathrm{C}$ and room temperature are shown in Table 4.

Table 4. Viability of Lactobacillus spp. conserved at $4^{\circ} \mathrm{C}$ and room temperature

\begin{tabular}{|c|c|c|}
\hline Strains & $4^{\circ} \mathrm{C}$ & Room temperature \\
\hline \multicolumn{3}{|l|}{ L. acidophilus biotype 1} \\
\hline IBNA 21 & $<48$ days & $<48$ days \\
\hline \multicolumn{3}{|l|}{ L. acidophilus biotype 3 : } \\
\hline IBNA 23 & $<48$ days & $<48$ days \\
\hline IBNA 26 & 48 days & 48 days \\
\hline IBNA 27 & $<48$ days & $<82$ days \\
\hline IBNA 28 & $<48$ days & $<90$ days \\
\hline IBNA 30 & $<48$ days & $<90$ days \\
\hline IBNA 35 & 51 days, a single passage & 51 days, a single passage \\
\hline IBNA 36 & 60 days & $<51$ days \\
\hline IBNA 40 & $<51$ days & $<51$ days \\
\hline L. crispatus IBNA 22 & 48 days & $<90$ days \\
\hline \multicolumn{3}{|l|}{ L. brevis biotype 2 : } \\
\hline IBNA 24 & 7 months, a single passage & $<60$ days \\
\hline IBNA 31 & 4 months, a single passage & 66 days, a single passage \\
\hline \multicolumn{3}{|l|}{ L. fermentum biotype 1 : } \\
\hline IBNA 25 & 7 months & $<3$ months \\
\hline IBNA 32 & 60 days & 60 days \\
\hline IBNA 37 & 90 days & 51 days, a single passage \\
\hline IBNA 42 & 90 days & 60 days \\
\hline IBNA 43 & 6 months, a single passage & 90 days \\
\hline L.delbrueckii ssp. delbrueckii, & $<48$ days & $<48$ days \\
\hline \multicolumn{3}{|l|}{ IBNA 38} \\
\hline \multicolumn{3}{|l|}{ L. salivarius: } \\
\hline IBNA 29 & 48 days, a single passage & 48 days, a single passage \\
\hline IBNA 33 & $<48$ days & $<48$ days \\
\hline IBNA 34 & $<51$ days & $<51$ days \\
\hline IBNA 39 & $<48$ days & $<48$ days \\
\hline IBNA 41 & $<51$ days & $<51$ days \\
\hline
\end{tabular}

L. fermentum strains survived $2-7$ months at $4^{\circ} \mathrm{C}$ and 51-90 days at room temperature, and L. brevis strains lived 4-7 months at $4{ }^{\circ} \mathrm{C}$ (a single passage), and 66 days at room temperature (a single passage), one strain from two tested. Most of L. acidophilus, L. delbrueckii, L. salivarius and L. crispatus isolates not survive 48 days at $4{ }^{\circ} \mathrm{C}$ and room temperature.

The origin of L. salivarius and L. acidophilus as bacterial source from humans, hamsters, horses, pigs, turkeys, and chickens, included them in the vertebrate adapted lifestyle lactobacilli group (DUAR \& al [8], SORESCU \& al [32]). DUAR \& al [8] affirmed that L. fermentum makes part from nomadic species group of lactobacilli and generally, was found in different sources as: milk-based products, fermenting vegetable material, sewage, mouth and humans' faeces, and intestines of pig, cattle, rat, mouse and birds, including turkeys.

As a host-adapted, Lactobacillus strains from chicken's intestinal tract, have high natural suitability, and so will be beneficial for evolving a probiotic multifarious in the poultry field. Moreover, higher fitness is relevant to outcompete pathogens.

SORESCU \& al [32] reported that the numbers of lactobacilli in turkey's cecum are higher $\left(10^{7}-10^{8}\right)$ compared to the ileum digesta $\left(10^{6}-10^{7}\right)$. Unlike the turkeys (perhaps due to the age interims-73 versus 26-and the species), L. fermentum has relative same presence to other lactobacilli in the GI content. This detail is motivating, because the $L$. fermentum is supposed to be nomadic species, while the L. salivarius and L. acidophilus is adapted to species of vertebrate. Besides, a representative level of Lactobacillus colonies in animal digesta can propose a better adaptation to the ecological niche and can naturally proliferate and involve better effects than other types of Lactobacillus strains isolated from other sources.

As phenotypical confirmation, APIweb ${ }^{\mathrm{TM}}$ and ABIS system demonstrated to be advantageous, expressly for L. acidophilus biotype 1, L. delbrueckii ssp. delbrueckii, 
L. salivarius and L. brevis biotype 2, where was obtained the identical identification.

The resistance at $4^{\circ} \mathrm{C}$ is a relevant strain property. An elongated resistance involves a positive strains property through their selection. L. fermentum biotype 1 and L. brevis biotype 2 isolates have resisted for the longest time. To prepare a probiotic product, the present results are suitable in screening the phenotypic characters where the resistance at least two months at $4^{\circ} \mathrm{C}$ is very important to analyze.

From this aspect, L. fermentum and L. brevis strains will be carefully chosen for testing several probiotic properties. Turkey strains of L. fermentum were previously selected for the same reason (SORESCU \& al [32]). In the literature data, this specific information was not found maybe of the benefices of probiotic products of industrial manufacturers. Anyway, it is known that the capability of probiotics to live during culture storage and to tolerate the passage through the stomach and to resist in the small intestine area important criterion of in vitro selection (UPADRASTA \& al [36]). PAPADIMITRIOU \& al [37] noticed that, generally, the strain viability, and the growth phase of the probiotic cell wall, seem to involve significant interaction with the host, so on its performance.

\section{Conclusions}

In conclusion, our results indicate that the cecum segment involves a higher number of lactobacilli $\left(10^{7}-10^{8}\right.$ $\mathrm{CFU} / \mathrm{g})$ than in the ileum $\left(10^{6}-10^{7} \mathrm{CFU} / \mathrm{g}\right)$, but unlike the turkeys, L. fermentum has relative same presence to other lactobacilli in the intestinal content. From isolated Lactobacillus strains, those from L. fermentum biotype 1 and $L$. brevis biotype 2 are technically apt for continual in vitro testing of potential as probiotic source for poultry.

\section{Acknowledgments}

This study was funded by the Romanian Ministry of Research and Innovation through the Nucleus Program (PN 19-09.01.04) and the Project 8PCCDI /2018-PC 2.

\section{Conflict of Interest}

The authors have no conflict of interest to report.

\section{References}

1. S. YADAV and R. JHA. Strategies to modulate the intestinal microbiota and their effects on nutrient utilization, performance, and health of poultry. J Anim Sci Biotechnol 10, 2 (2019). https://doi.org/10.1186/ s40104-018-0310-9

2. K. SLIZEWSKA, P. MARKOWIAK-KOPEC, A. ZBIKOWSKI, and P. SZELESZCZUK. The effect of symbiotic preparations on the intestinal microbiota and her metabolism in broiler chickens. Sci Rep 10, 4281 (2020). https://doi.org/10.1038/s41598-020-61256-Z

3. D.R. RODRIGUES, W. BRIGGS, A. DUFF, K. CHASSER, R. MURUGESAN, C. PENDER, S. RAMIREZ, L. VALENZUELA, and L. R. BIELKE.
Comparative effectiveness of probiotic-based formulations on cecal 3 microbiota modulation in broilers. PLoS One 15, e0225871 (2020). https://doi.org/ 10.1371/journal.pone.0225871

4. BARBOSA, V. BALAGUÉ, F. VALERA, A. MARTÍNEZ, J. BENZA, M. MOTAS and C. PEDRÓS-ALIÓ. Age-related differences in the gastrointestinal microbiota of chinstrap penguins (Pygoscelis antarctica). Plos One 11(4), e0153215 (2016). doi:10.1371/journal.pone.0153215

5. C. CiURESCU, M. DUMITRU, A. GHEORGHE, A. UNTEA, and R. DRAGHICI. Effect of Bacillus subtilis on growth performance, bone mineralization, and bacterial population of broilers fed with different protein sources. Poult Sci 99(11), 5960-5971 (2020). https://doi.org/10.1016/j.psj.2020.08.075

6. M. DUMitRU, M. HĂBEANU, N. LEFTER and A. GHEORGHE, 2020. The effect of Bacillus licheniformis as direct-fed microbial product on growth performance, gastrointestinal disorders and microflora population in weaning piglets. Rom Biotechnol Lett 25(6), 2060-2069. doi: 10.25083/rbl/25.6/2060.2069

7. E. AMIT-ROMACH, D. SKLAN, and Z. UNI. Microflora ecology of the chicken intestine using $16 \mathrm{~S}$ ribosomal DNA primers. Poult Sci 83, 1093-1098 (2004).

8. R.M. DUAR, X.B. LIN, J. ZHENG, M.E. MARTINO, T. GRENIER, M.E. PEREZ-MUNOZ, F. LEULIER, M. GANZLE and J. WALTER. Lifestyles in transition: evolution and natural history of the genus Lactobacillus. FEMS Microbiol Rev 30(41), 27-48 (2017).

9. D.W. WAITE and M.W. TAILOR. Characterizing the avian gut microbiota: membership, driving influences, and potential function. Front Microbiol 5, article 223, 1-12, (2014).

10. S. WEI, M. MORRISON, and Z. YU. Bacterial census of poultry intestinal microbiome. Poult Sci 92(3), 671-683 (2013).

11. J. LU, U. IDRIS, B. HARMON, C. HOFACRE, J.J. MAURER and M.D. LEE. Diversity and succession of the intestinal bacterial community of the maturing broiler chicken. Appl Environ Microbiol 69(11), 68166824 (2003).

12. N. AAZAMI, G.S. JOUZANI, Z. KHODAEI, A. MEIMANDIPOUR, M. SAFARI and M. GOUDARZVAND. Characterization of some potentially probiotic Lactobacillus strains isolated from Iranian native chickens. J. Gen. Appl Microbiol 60, 215-221 (2014).

13. X.Y. ZHU, T. ZHONG, Y. PANYA and R.D. JORGER. 16S rRNA-based analysis of microbiota from the cecum of broiler chickens. Appl Environ Microbiol 68, 124-137 (2002).

14. M. KIZERWETTER-SWIDA and M. BINEK. Assessment of potentially probiotic properties of Lactobacillus strains isolated from chickens. Pol J Vet Sci 19, 15-20 (2016).

15. N. NOOHI, G. EBRAHIMIPOUR, M. ROHANI, M. TALEBI and M. POURSHAFIE. Phenotypic characteristics and probiotic potentials of Lactobacillus spp. isolated from poultry. Jundishapur J Microbiol 7:e17824 (2014). 
16. G. AZIZ, H. FAKHAR, S. UR. RAHMAN, T. MUHAMAMMAD, and A. ZAIDI. An assessment of the aggregation and probiotic characteristics of Lactobacillus species isolated from native (desi) chicken gut. Journal of Applied Poultry Research 28(4), 846-857 (2019). doi:10.3382/japr/pfz042

17. M. PINEIRO, and C. STANTON C. Probiotic bacteria: legislative framework-requirements to evidence basis. J Nutr 137(3), 850S-853S (2007).

18. H. AL-KHALAIFA H, A. AL-NASSER, T. ALSURAYEE, S. AL-KANDARI, N. AL-ENZI, T. ALSHARRAH, G. RAGHEB, S. AL-QALAF, and A. MOHAMMED. Effect of dietary probiotics and prebiotics on the performance of broiler chickens. Poult Sci 98(10), 4465-4479 (2019).

19. K. GHAREEB, W.A. AWAD, M. MOHNL, R. PORTA, M. BIARNES, J. BÖHM and G. SCHATZMAYR. Evaluating the efficacy of an avian-specific probiotic to reduce the colonization of Campylobacter jejuni in broiler chickens. Poult Sci 91(8), 1825-1832 (2012).

20. J.M. NEAL-MCKINNEY, X. LU, T. DUONG, C.L. LARSON, D.R. CALL, D. H. SHAH and M.E. KONKEL. Production of organic acids by probiotic lactobacilli can be used to reduce pathogen load in poultry. PloS One 7, e43928 (2012). https://doi.org/ 10.1371/journal.pone.0043928

21. M. KHAN, A.A. ANJUM, M. NAWAZ, A.R. AWAN, and M.A. ALI. Effect of newly characterized probiotic lactobacilli on weight gain, immunomodulation and gut microbiota of Campylobacter jejuni challenged broiler chicken. Pak Vet J, 39(4): 473-478. (2019). http://dx.doi.org/10.29261/pakvetj/2019.051

22. Z. LI, W. WANG, D. LIU and Y. GUO. Effects of Lactobacillus acidophilus on gut microbiota composition in broilers challenged with Clostridium perfringens. PloS One 12, e0188634 (2017). https://doi.org/ 10.1371/journal.pone.0188634

23. M. DUMITRU, M. HABEANU, N. LEFTER. Effects of direct-feed microbial Bacillus supplementation on piglet's microbiota. Scientific Bulletin. Series F. Biotechnologies 24(2), 154-160 (2020). ISSN 22851364, CD-ROM ISSN 2285-5521, ISSN Online 22851372, ISSN-L 2285-1364.

24. M. KIZERWETTER-SWIDA, and M. BINEK. Protective effect of potentially probiotic Lactobacillus strain on infection with pathogenic bacteria in chickens. Pol J Vet Sci 12(1), 15-20 (2009).

25. G. TELLEZ, C. PIXLEY, R. WOLFENDEN, S LAYTON, and B. HARGIS. Probiotics/direct fed microbials for Salmonella control in poultry. Food Res Int 45, 628-633 (2012).

26. J. D. KOWALSKA, A. NOWAK, K. ŚLIŻEWSKA, M. STAŃCZYK and J. DASTYCH. Anti-Salmonella potential of new Lactobacillus strains with the application in the poultry industry. Pol J Microbiol 69(1), 5-18 (2020).

27. F. GAGGÌA, P. MATTARELLI, and B. BIAVATI. Probiotics and prebiotics in animal feeding for safe food production. Int J Food Microbiol 141, S15-S28 (2010).

28. J. FENG, L. WANG, L. ZHOU, X. YANG and X. ZHAO. Using in vitro immunomodulatory properties of lactic acid bacteria for selection of probiotics against Salmonella infection in broiler chicks. PLoS One 11, e0147630 (2016). https://doi.org/10.1371/journal. pone. 0147630

29. R.C. REUBEN, P.C. ROY, S.L. SARKAR, R.U. ALAM and I.K. JAHID. Isolation, characterization, and assessment of lactic acid bacteria toward their selection as poultry probiotics. BMC Microbiol 19, 253 (2019). https://doi.org/10.1186/s12866-019-1626-0

30. A. ZOU, S. SHARIF and J. PARKINSON. Lactobacillus elicits a 'Marmite effect' on the chicken cecal microbiome. Nature partner journals, Biofilms and Microbiomes 4(27), 1-5 (2018). doi: 10.1038/s41522018-0070-5

31. K.C. MOUNTZOURIS, P. TSIRTSIKOS, E. KALAMARA, S. NITSCH, G. SCHATZMAYR and K. FEGEROS. Evaluation of the efficacy of a probiotic containing Lactobacillus, Bifidobacterium, Enterococcus, and Pediococcus strains in promoting broiler performance and modulating cecal microflora composition and metabolic activities. Poult Sci 86, 309-317 (2007).

32. I. SORESCU, M. DUMITRU and G. CIURESCU. Lactobacillus spp. and Enterococcus faecium strains isolation, identification, preservation and quantitative determinations from turkey gut content. Rom Biotechnol Lett 24(1): 41-49 (2019). doi: 10.25083/rbl/24.1/41.49

33. C. STOICA and I. SORESCU. ABIS online-Advanced Bacterial Identification Software, an original tool for phenotypic bacterial identification. Regnum Prokaryotae- www.tgw1916.net, september 1 (2017).

34. D.R. PELINESCU, E. SĂSĂRMAN, M.C. CHIFIRIUC, I. STOICA, A.M. NOHIT, I. AVRAM, F. SERBANCEA, and T.V. DIMOV. Isolation and identification of some Lactobacillus and Enterococcus strains by a polyphasic taxonomical approach. Rom Biotechnol Lett 14 (2), 4225-4233 (2009).

35. E.P. CATO, W.E.C. MOORE and J.L. JOHNSON. Synonymy of strains of Lactobacillus acidophilus Group A2. (Johnson et al., 1980) with the type strain of Lactobacillus crispatus (Brygoo and Aladame, 1953) Moore and Holdeman 1970. Int J Syst Bacteriol 33 (2), 426-428 (1983).

36. A. UPADRASTA, C. STANTON, C. HILL, G. FITZGERALD, and R.P. ROSS. Improving the stress tolerance of probiotic cultures: recent trends and future directions. In: E. TSAKALIDOU and K. PAPADIMITRIOU (eds.), Stress Responses of Lactic Acid Bacteria, Springer, New York, 395-438 (2011).

37. K. PAPADIMITRIOU, G. ZOUMPOPOULOU, B. FOLIGNE, V. ALEXANDRAKI, M. KAZOU, B. POT and E. TSAKALIDOU. Discovering probiotic organisms: in vitro, in vivo, genetic and omics approaches. Front Microbiol, Food Microbiol 6(58), 1-28 (2015). doi: 10.3389/fmicb.2015.00058 